\title{
Upregulation of nerve growth factor expression by human airway smooth muscle cells in inflammatory conditions
}

\author{
V. Freund*, F. Pons*, V. Joly*, E. Mathieu*, N. Martinet" ${ }^{\#}$ N. Frossard*
}

Upregulation of nerve growth factor expression by human airway smooth muscle cells in inflammatory conditions. V. Freund, F. Pons, V. Joly, E. Mathieu, N. Martinet, N. Frossard. C ERS Journals Ltd 2002.

ABSTRACT: Recent studies have suggested that nerve growth factor (NGF) may play a role in inflammation and bronchial hyperresponsiveness in asthma. Neither the types of cells that produce NGF in the human airways nor the effect of inflammation on NGF expression are clear. The two-fold aim of the present study was to determine whether airway smooth muscle produces NGF in vitro, and, if so, whether the pro-inflammatory

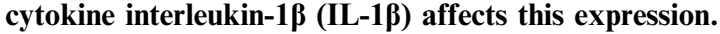

Human airway smooth muscle cells in culture were incubated in the presence or absence of IL-1ß. NGF production was measured by enzyme-linked immunosorbent assay. NGF messenger ribonucleic acid (mRNA) was measured using a specific realtime fluorescent polymerase chain reaction technique, and expressed in relation to glyceraldehyde-3-phosphate dehydrogenase (GAPDH) mRNA levels.

Human airway smooth muscle cells in vitro expressed NGF constitutively (21.4 \pm $7.8 \mathrm{pg} \cdot \mathrm{mL}^{-1} ; 14.6 \pm 5.4 \mathrm{pg}$ NGF complementary deoxyribonucleic acid (cDNA) $\cdot \mathrm{pg}$ GAPDH cDNA $^{-1}$ (mean \pm SEM)). Stimulation with IL-1ß $\left(0.1-30 \mathrm{U} \cdot \mathrm{mL}^{-1}\right)$ for $24 \mathrm{~h}$ induced a dose-dependent increase in NGF production $\left(22.1 \mathrm{pg} \cdot \mathrm{mL}^{-1}\right.$ at $10 \mathrm{U} \cdot \mathrm{mL}^{-1}$; $p<0.05)$. The IL-1 $\beta\left(10 \mathrm{U} \cdot \mathrm{mL}^{-1}\right)$-induced increase in NGF expression was timedependent. It was highest for NGF protein at $10 \mathrm{~h}$ (1.6-fold increase over control; $p<0.001)$ and for NGF mRNA at $2.5 \mathrm{~h}(2.4$-fold increase over control; $p<0.05)$.

In conclusion, the present study clearly shows that the human airway smooth muscle cell is a source of nerve growth factor, the expression of which is upregulated in inflammatory conditions, mimicked in vitro by the addition of interleukin-1 $\beta$. Eur Respir J 2002; 20: 458-463.
*National Institute of Health and Medical Research (INSERM), Unit 425, "Neuroimmunopharmacologie pulmonaire", Faculty of Pharmacy, University Louis Pasteur-Strasbourg I, Illkirch, and "Clerc Poumon" Faculty of Medicine, University PoincaréNancy I, Nancy, France.

Correspondence: N. Frossard, INSERM U425, Neuroimmunopharmacologie pulmonaire, Faculté de pharmacie, Université Louis Pasteur-Strasbourg I, B.P. 24, 67401 Illkirch Cedex, France.

Fax: 33390244309

E-mail: nelly.frossard@pharma.

u-strasbg.fr

Keywords: Airway

asthma

inflammation

interleukin- $1 \beta$

nerve growth factor

smooth muscle

Received: August 72001

Accepted after revision: October 25 2001
Nerve growth factor (NGF) is a well known neurotrophin whose activity is essential for nerve growth and survival (reviewed in [1, 2]). Recent reports of both animal and human studies suggest that NGF functions as an important inflammatory mediator (reviewed in [3, 4]). NGF modulates immunological and inflammatory processes by enhancing the survival and/or activation of lymphocytes [5], eosinophils [6, 7] and neutrophils [8]. Its action on the mast cell is particularly important. NGF causes an increase in the number of mast cells in peripheral tissue [2, 9], promotes mast-cell differentiation [10] and survival [11], and promotes and enhances mediator release from mast cells [12-14]. It may therefore contribute to the increase in number and degranulation of mast cells in tissue.

In addition, various animal studies suggest that NGF may contribute to the development of airway hyperresponsiveness. First, antibodies directed against NGF block the bronchial hyperresponsiveness (BHR) induced by NGF in sensitised and challenged mice [15]. In addition, BHR is induced by tissuespecific overexpression of NGF in the airways [16]. Finally, NGF by itself induces hyperresponsiveness in guinea-pig airways [17], as well as in human bronchi in vitro [18]. NGF may thus be suggested to play a central role in airway inflammation, through its effects on mast cells, and to participate in the increased BHR observed in asthma.

Structural cells, particularly pulmonary epithelial cells $[19,20]$ and fibroblasts [21], as well as vascular smooth muscle cells [22, 23], synthesise and secrete NGF. To date, however, NGF expression by airway smooth muscle cells has not been reported. For this reason, it was examined whether airway smooth muscle cell is a source of NGF in humans, and, if so, whether this expression might be regulated in inflammatory conditions, which were mimicked in vitro by addition of the pro-inflammatory cytokine interleukin (IL) $-1 \beta$.

\section{Material and methods}

Primary culture of human airway smooth muscle cells

Human airway smooth muscle was obtained from healthy lung transplant donors after sudden death 
(France-Transplant, Nancy, France). Bronchial smooth muscle was carefully dissected out, cut into small fragments and cultured in Roswell Park Memorial Institute (RPMI) 1650 medium containing L-glutamine $(2 \mathrm{mM})$, penicillin $\left(50 \mathrm{U} \cdot \mathrm{mL}^{-1}\right)$ and streptomycin $\left(50 \mu \mathrm{g} \cdot \mathrm{mL}^{-1}\right)$, and supplemented with $10 \%$ foetal bovine serum (FBS). The muscle cells were cultured in $75 \mathrm{~cm}^{2}$ flasks (Costar, Cambridge, MA, USA) in air containing $5 \%$ carbon dioxide in a humidified chamber at $37^{\circ} \mathrm{C}$, with the medium changed twice weekly (all products supplied by GIBCO BRL, Cergy Pontoise, France). Cultures were rinsed in Hank's balanced salt solution, trypsinised (trypsin/ethylene diamine tetra-acetic acid) for $3 \mathrm{~min}$, centrifuged at $200 \times g$ for $5 \mathrm{~min}$, and cultured in Dulbecco modified Eagle medium (DMEM)/F12 supplemented with 10\% FBS, nonessential amino acids (1\%), L-glutamine (2 mM), penicillin $\left(50 \mathrm{U} \cdot \mathrm{mL}^{-1}\right)$, streptomycin $\left(50 \mu \mathrm{g} \cdot \mathrm{mL}^{-1}\right)$ (all from GIBCO BRL) and insulin $\left(5 \mu \mathrm{g} \cdot \mathrm{mL}^{-1}\right)$ (Lilly, St-Cloud, France). Cells were used experimentally at passage 6-8. They were characterised as smooth muscle cells morphologically (typical "hills and valleys" morphology) and immunocytochemically, using antibodies directed against vimentin and smooth muscle $\alpha$-actin (Dako, Trappes, France), and showed $98 \%$ purity.

\section{Experimental procedure}

Cells were starved in low-FBS $(0.3 \%)$ insulin-free DMEM/F12 for $24 \mathrm{~h}$. The dose-dependent effect of IL-1 $\beta$ was studied by stimulating cells in the absence or presence of increasing concentrations of IL-1 $\beta$ (0.1-30 U $\left.\cdot \mathrm{mL}^{-1}\right)$ (Boehringer Mannheim, Mannheim, Germany) for $24 \mathrm{~h}$. The time course of NGF expression was studied in the presence and absence of IL-1 $\beta\left(10 \mathrm{U} \cdot \mathrm{mL}^{-1}\right)$ at $1.5,2.5,3.5,5$ and $10 \mathrm{~h}$. Cell supernatant was collected, kept on ice, centrifuged $\left(13,000 \times g, 5 \mathrm{~min}, 4^{\circ} \mathrm{C}\right)$, and stored at $-20^{\circ} \mathrm{C}$ until NGF protein measurement. Cells were collected in $1 \mathrm{~mL}$ ribonucleic acid (RNA) extraction reagent (TriReagent $(\mathrm{B})$; Sigma Aldrich, St-Quentin Fallavier, France) and kept at $-20^{\circ} \mathrm{C}$ until analysis.

\section{Quantification of nerve growth factor by enzyme-linked immunosorbent assay}

A highly sensitive, commercially available, NGFspecific two-site enzyme-linked immunosorbent assay (ELISA) kit (Promega, Madison, WI, USA) was used according to the manufacturer's instructions to quantify NGF in the supernatant of control and treated smooth muscle cells. Briefly, 96-well immunoplates (Maxisorp $^{\text {TM}}$; Nunc, Roskilde, Denmark) were coated with polyclonal goat antihuman NGF antibody in coating buffer ( $25 \mathrm{mM}$ carbonate buffer, $\mathrm{pH} 9.7)$. After overnight incubation at $4{ }^{\circ} \mathrm{C}$, the plates were washed (20 mM tris-(hydroxymethyl)-aminomethane (Tris)/hydrochloric acid ( $\mathrm{pH} 7.4), 150 \mathrm{mM}$ sodium chloride containing $0.05 \%$ (volume/volume) Tween $\mathbb{R}$ 20; Sigma Aldrich) and incubated in blocking buffer for $1 \mathrm{~h}$. The supernatants and standard recombinant human NGF dilutions in the low-FBS medium were added to the wells and incubated for $\geqslant 6 \mathrm{~h}$ at $37^{\circ} \mathrm{C}$, and the wells were washed. Rat monoclonal anti-NGF antibody $\left(0.25 \mu \mathrm{g} \cdot \mathrm{mL}^{-1}\right)$ was added, overnight incubation was performed at $4{ }^{\circ} \mathrm{C}$ and the wells were washed. Antirat horseradish peroxidase-conjugated immunoglobulin $G$ was added and the wells were incubated for $2.5 \mathrm{~h}$. Substrate $\left(3,3^{\prime}, 5,5^{\prime}\right.$-tetramethylbenzidine $0.02 \%$ and hydrogen peroxidase $0.01 \%$ ) was then added and the colorimetric reaction stopped after 10 min by adding phosphoric acid (1 M). Optical density was measured in duplicate at $450 \mathrm{~nm}$. The technique made it possible to detect $\mathrm{NGF}$ in the culture supernatant in the range $3.9-500 \mathrm{pg} \cdot \mathrm{mL}^{-1}$ without any interference.

\section{Extraction of total ribonucleic acid and reverse transcription}

A modified guanidine thiocyanate technique, with phenol/chloroform extraction of total RNA [24], was used as previously described $[25,26]$. Cells in TriReagent (R) were mixed with chloroform (Sigma Aldrich), agitated on a vortex mixer for $15 \mathrm{~min}$ and incubated for $15 \mathrm{~min}$ at room temperature. After centrifugation $\left(13,000 \times g, 4^{\circ} \mathrm{C}\right)$, RNA was precipitated in isopropanol (Sigma Aldrich) for $10 \mathrm{~min}$ at room temperature, centrifuged $\left(13,000 \times g, 4^{\circ} \mathrm{C}\right)$ and dried at room temperature for $30 \mathrm{~min}$. The isolated RNA was then diluted in ribonuclease (RNase)-free water. The RNA was extracted a second time, using the same procedure, to avoid any possible genomic deoxyribonucleic acid (DNA) contamination. Total RNA was incubated with $0.5 \mu \mathrm{g}$ random primers for $5 \mathrm{~min}$ at $70^{\circ} \mathrm{C}$ and allowed to cool down to room temperature. The RNA was subsequently reverse-transcribed in $1 \times$ reverse transcription buffer $(75 \mathrm{mM}$ potassium chloride, $15 \mathrm{mM}$ magnesium chloride, $10 \mathrm{mM}$ dithiothreitol, $50 \mathrm{mM}$ Tris, $\mathrm{pH} 8.5$ ) containing $1 \mathrm{U} \cdot \mu \mathrm{L}^{-1}$ RNase H-minus Moloney murine leukaemia virus reverse transcriptase (all reagents from Promega). The reaction was conducted for $1 \mathrm{~h}$ at $37^{\circ} \mathrm{C}$, and the reverse transcriptase was then inactivated by heating at $99^{\circ} \mathrm{C}$ for $5 \mathrm{~min}$. A negative control was performed without reverse transcriptase, and the complementary DNA (cDNA) product analysed by electrophoresis on a $2 \%$ agarose gel containing ethidium bromide (Euromedex, Souffelweyersheim, France) to verify the absence of genomic DNA contamination.

Quantification of nerve growth factor complementary deoxyribonucleic acid by polymerase chain reaction

The reverse transcription product $(1 \mu \mathrm{L}$ of a $1: 20$ dilution) was amplified by polymerase chain reaction $(\mathrm{PCR})$ in $1 \times \mathrm{PCR}$ reaction buffer: $2 \mu \mathrm{L}$ of the reaction mix (Lightcycler-Faststart reaction Mix SYBR Green I; Roche Molecular Biochemicals, Mannheim, Germany), containing FastStart Taq DNA polymerase, deoxyribonucleoside triphosphate mix, SYBR Green I, $2.5 \mathrm{mM}$ magnesium chloride, together with $0.4 \mu \mathrm{M}$ of each primer (Invitrogen, Cergy Pontoise, France), sense 5'-CCAAGGGAGCAGCTTTCTATCCTGG-3' 
and antisense 5 '-GGCAGTGTCAAGGGAATGCTGAAGT-3', in a final volume of $20 \mu \mathrm{L}$ for 35 cycles $(15 \mathrm{~s}$ denaturation at $95^{\circ} \mathrm{C}, 10 \mathrm{~s}$ hybridisation at $58^{\circ} \mathrm{C}, 8 \mathrm{~s}$ elongation at $72^{\circ} \mathrm{C}$ ) in a real-time fluorescent quantitative PCR thermocycler (Lightcycler, Roche Molecular Biochemicals). NGF cDNA was quantified on-line via SYBR Green fluorescence. A standard curve was obtained from amplification of a specific NGF cDNA purified after agarose extraction (Qiaex IIß); Qiagen S.A., Courtaboeuf, France) and fluorescent quantification with Picogreen $\mathbb{R}$ (DNA Quantification reagent; Interchim, Montluçon, France). The specificity of the 189-base pair PCR product was validated using the fusion curve obtained after each reaction (Lightcycler) by electrophoresis, as well as by molecular sequencing. Results were normalised to glyceraldehyde-3-phosphate dehydrogenase (GAPDH) expression, similarly quantified (Lightcycler) using $0.4 \mu \mathrm{M}$ of each primer, sense 5'-GGTGAAGGTCGGAGTCAACGGA-3' and antisense 5'-GAGGGATCTCGCTCCTGGAAGA-3', in a final volume of $20 \mu \mathrm{L}$ for 45 cycles $\left(15 \mathrm{~s}\right.$ denaturation at $95^{\circ} \mathrm{C}$, $10 \mathrm{~s}$ hybridisation at $57^{\circ} \mathrm{C}, 10 \mathrm{~s}$ elongation at $72^{\circ} \mathrm{C}$ ).

\section{Expression of results and statistical analysis}

NGF levels are formulated either as picograms of NGF per millilitre of culture supernatant or as a percentage of control secretion. NGF messenger RNA (mRNA) expression is formulated either as the ratio of NGF cDNA to GAPDH cDNA, and expressed as fg NGF cDNA.pg GAPDH $\mathrm{cDNA}^{-1}$, or as a percentage of control secretion. Results are presented as mean \pm SEM of six independent experiments performed in duplicate on airway smooth muscle cells obtained from three different donors. Differences between groups were analysed from raw data using an unpaired two-tailed t-test and two-way analysis of variance. Student-Newman-Keuls test was used to compare more than two variables. Data were considered significant at $\mathrm{p}<0.05$.

\section{Results}

\section{Constitutive nerve growth factor expression}

Cultured airway smooth muscle cells expressed NGF constitutively (NGF protein: $21.4 \pm 7.8 \mathrm{pg} \cdot \mathrm{mL}^{-1}$, NGF cDNA: $14.6 \pm 5.4 \mathrm{fg} \cdot \mathrm{pg}$ GAPDH cDNA ${ }^{-1}$ (mean \pm SEM)).

\section{Effect of interleukin-1 $\beta$ on nerve growth factor expression}

IL-1 $\beta \quad\left(1-30 \mathrm{U} \cdot \mathrm{mL}^{-1}\right)$ significantly and dosedependently enhanced NGF protein secretion after $24 \mathrm{~h}(\mathrm{p}<0.05)$ (fig. 1). The maximum increase in NGF production occurred at $10 \mathrm{U} \cdot \mathrm{mL}^{-1}$ (from $21.4 \pm 7.8$ to $\left.43.5 \pm 4.8 \mathrm{pg} \cdot \mathrm{mL}^{-1}\right)$, corresponding to a 2.0 -fold increase over constitutive secretion levels.

The increase in NGF protein expression induced by IL-1 $\beta\left(10 \mathrm{U} \cdot \mathrm{mL}^{-1}\right)$ was time-dependent and was

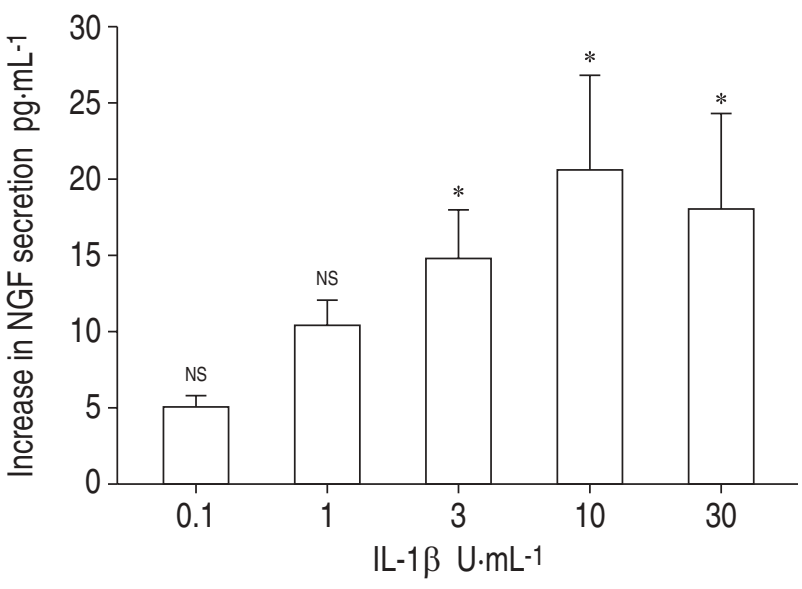

Fig. 1. - Dose-dependent effect of interleukin-1 $\beta$ (IL-1 $\beta$ ) on nerve growth factor (NGF) production by human airway smooth muscle cells in culture (increase over baseline level of $21.4 \pm 7.8 \mathrm{pg}$ $\mathrm{NGF} \cdot \mathrm{mL}$ supernatant $\left.{ }^{-1}\right)$. Data are expressed as mean \pm SEM of six independent experiments performed in duplicate on cells from three different donors. NS: nonsignificant. *: $\mathrm{p}<0.05$ versus control.

greatest at $10 \mathrm{~h}$ (from $19.5 \pm 5.3$ to $31.6 \pm 4.7 \mathrm{pg} \cdot \mathrm{mL}^{-1}$ ), i.e. an $11.5 \mathrm{pg} \cdot \mathrm{mL}^{-1}$, or 1.6 -fold increase over constitutive secretion levels $(\mathrm{p}<0.001)$ (fig. $2 \mathrm{a})$.

NGF mRNA levels were highest after $2.5 \mathrm{~h}$ of treatment (increasing from $13.2 \pm 4.3$ to $31.9 \pm 5.2 \mathrm{pg}$ NGF cDNA.pg GAPDH $\mathrm{cDNA}^{-1}$ ), i.e. an $18.7 \mathrm{fg}$ NGF cDNA.pg GAPDH $\mathrm{cDNA}^{-1}$, or 2.4-fold increase over baseline levels $(\mathrm{p}<0.05)$ (fig. $2 \mathrm{~b})$. Levels returned progressively to baseline within $10 \mathrm{~h}$.

\section{Discussion}

The present study clearly shows that airway smooth muscle cells in culture produce NGF, and that this production increases in response to the pro-inflammatory cytokine IL-1 $\beta$.

The finding that human airway smooth muscle cells express NGF is consistent with and an extension of earlier reports that human smooth muscle cells of other origin, particularly vascular smooth muscle cells, express and secrete NGF [22, 23]. It also adds to knowledge regarding the cellular sources of NGF in the human lung, since other structural cells, such as fibroblasts [21] and epithelial cells [19, 20], as well as various inflammatory cells, such as mast cells [27], T-and B-cells [28, 29], eosinophils [7], and macrophages [30] (reviewed in [4]), have previously been reported to secrete $\mathrm{NGF}$ in vitro. The in vitro secretion of $\mathrm{NGF}$ by airway smooth muscle cells is also consistent with reports of NGF-positive immunolabelling of bronchial smooth muscle in bronchial biopsy samples from controls and/or asthmatic patients [31, 32]. The present data also provide evidence that NGF secretion is enhanced when airway smooth muscle cells are stimulated by IL-1 $\beta$, a pro-inflammatory cytokine present in large quantities in the airways of asthmatic patients [33, 34]. Similarly, enhanced NGF secretion has been reported in other structural cells stimulated by IL-1 $\beta$, including pulmonary fibroblasts [21] and 

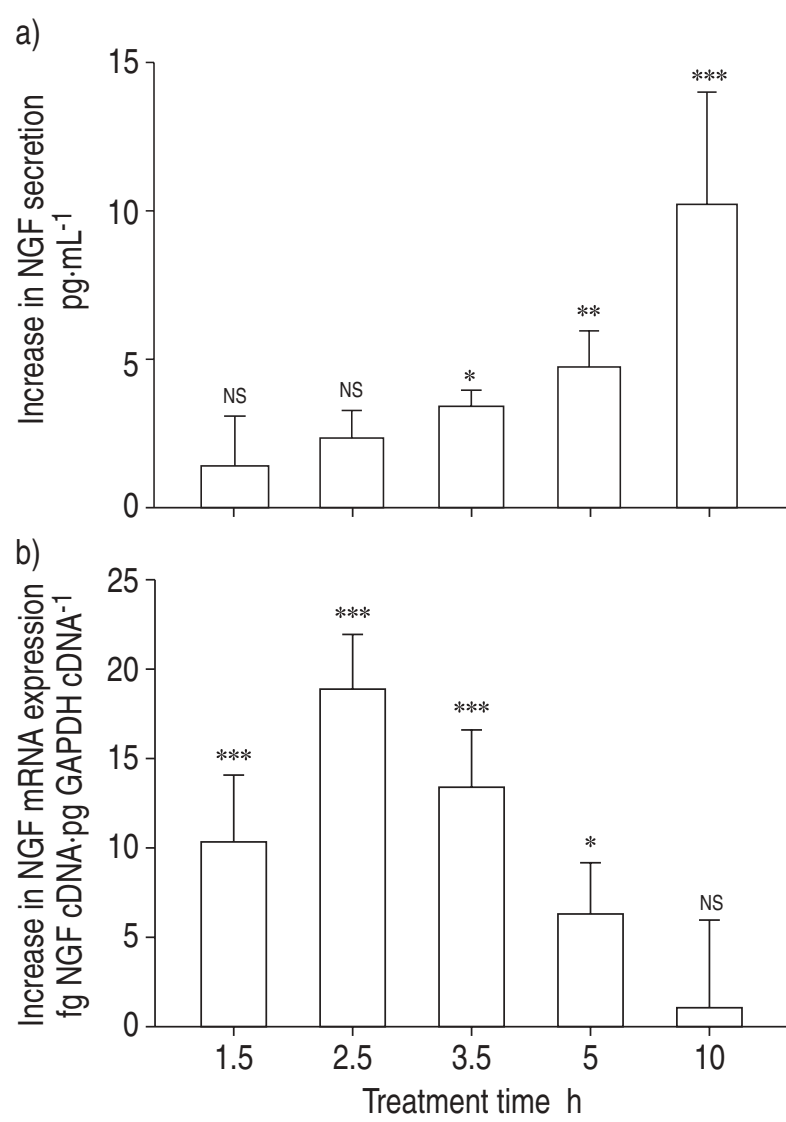

Fig. 2. - Time course of effect of interleukin-1 $\beta\left(10 \mathrm{U} \cdot \mathrm{mL}^{-1}\right)$ on expression of a) nerve growth factor (NGF) and b) NGF messenger ribonucleic acid (mRNA). Data are presented as mean \pm SEM of six independent experiments performed in duplicate on cells from three different donors. cDNA: complementary deoxyribonucleic acid; GAPDH: glyceraldehyde-3-phosphate dehydrogenase; NS: nonsignificant. *: $\mathrm{p}<0.05$ versus control; **: $\mathrm{p}<0.01$ versus control; $* * *: \mathrm{p}<0.001$ versus control.

human astrocytoma and glioblastoma cell lines [35]. This acquisition of a secretory phenotype by airway smooth muscle cells in culture after stimulation by proinflammatory agents, such as IL-1 $\beta$ or tumour necrosis factor- $\alpha$, has been described as a new characteristic of airway smooth muscle [36, 37]. In particular, production of eotaxin [38] and granulocyte-macrophage colony-stimulating factor [39] are enhanced by IL-1 $\beta$. Accordingly, overexpression of NGF by airway smooth muscle cells under inflammatory conditions mimicked by IL-1 $\beta$ in vitro, may be interpreted as confirmation that smooth muscle plays an active role in airway inflammation. It was also observed that the increase in NGF secretion induced by IL-1 $\beta$ was time-dependent and maximal after $10 \mathrm{~h}$. This enhanced expression was preceded by increased NGF mRNA levels, which reached a maximum at $2.5 \mathrm{~h}$. NGF transcription may be increased by IL-1 $\beta$-induced activation of inflammatory transcription factors, such as activated protein-1 [40], since the activated protein-1 responsive element is present in the NGF gene promoter [41].

Excessive amounts of IL-1 $\beta$ have been implicated in the pathogenesis of various inflammatory conditions of the lung and airways, including asthma [33, 34].
IL-1 $\beta$ is produced by various cell types, particularly the infiltrated mast cells, many of which are found within the smooth muscle layer [42]. The dose of IL-1 $\beta$ used in the present study was within its biological range of action [43]. This suggests that increased levels of NGF might occur in inflammatory airway conditions. Indeed, enhanced NGF levels have been reported in the serum of patients with inflammatory diseases, particularly asthma [44]. Higher levels of NGF have also been reported in the bronchoalveolar [45] and nasal [46] lavage fluid of patients with asthma and rhinitis, respectively, compared with those of control subjects. Similarly, higher NGF levels have also been found in patients with asthma after allergen challenge [47]. Therefore, airway smooth muscle cells, which are capable of producing elevated levels of NGF after IL-1 $\beta$ stimulation, may participate in increasing NGF levels in inflamed airways. The increased NGF expression might play a role in the hyperresponsiveness observed in airway inflammatory conditions. Indeed, NGF causes hyperresponsiveness of guineapig [17] as well as of human [18] airways in vitro. In addition, NGF alone induces BHR in mice after lungspecific genetic overexpression [16]. Also, BHR induced by allergen challenge in sensitised mice in vivo is abolished by an antibody directed against NGF [15]. Hence, the authors propose that increased airway smooth muscle cell expression of NGF as demonstrated in the present study may play a role in BHR in asthma.

In conclusion, the present study shows that human airway smooth muscle may be an important source of nerve growth factor, and that interleukin-1 $\beta$, a pro-inflammatory cytokine, may enhance this nerve growth factor secretion. This finding, together with recent reports that nerve growth factor is linked to asthma-associated symptoms in animals [15-17], suggests that airway smooth muscle, by increasing nerve growth factor secretion during airway inflammation, plays an important role in this inflammation.

\section{References}

1. Levi-Montalicini R, Skaper SD, Dal Toso R, Petrelli L, Leon A. Nerve growth factor: from neurotrophin to neurokine. Trends Neurosci 1996; 19: 514-520.

2. Aloe L, Bracci-Laudiero L, Bonini S, Manni L. The expanding role of nerve growth factor: from neurotrophic activity to immunologic disease. Allergy 1997; 52: 883-894.

3. Bonini S, Lambiase A, Bonini S, Levi-Schaffer F, Aloe L. Nerve growth factor: an important molecule in allergic inflammation and tissue remodeling. Int Arch Allergy Immunol 1999; 118: 159-182.

4. Olgart C, Frossard N. Nerve growth factor and asthma. Pulm Pharm Ther 2002; 15: 51-60.

5. Otten U, Ehrhard P, Peck R. Nerve growth factor induces growth and differentiation of human B lymphocytes. Proc Natl Acad Sci USA 1989; 86: 10059-10063.

6. Hamada A, Watanabe N, Ohtomo H, Matsuda H. Nerve growth factor enhances survival and cytotoxic activity of human eosinophils. J Haematol 1996; 93: 299-302.

7. Solomon A, Aloe L, Pe'er J, et al. Nerve growth factor 
is preformed in and activates human peripheral blood eosinophils. J Allergy Clin Immunol 1998; 102: 454 460.

8. Kannan $\mathrm{Y}$, Ushio $\mathrm{H}$, Koyama $\mathrm{H}$, et al. $2.5 \mathrm{~S}$ nerve growth factor enhances survival, phagocytosis, and superoxide production of murine neutrophils. Blood 1991; 77: 1320-1325.

9. Aloe L, Levi-Montalcini R. Mast cells increase in tissues of neonatal rats injected with the nerve growth factor. Brain Res 1977; 16: 358-366.

10. Matsuda H, Kannan Y, Ushio H, et al. Nerve growth factor induces development of connective tissue-type mast cells in vitro from murine bone marrow cells. J Exp Med 1991; 174: 7-14.

11. Bullock ED, Johnson EM Jr. Nerve growth factor induces the expression of certain cytokine genes and bcl-2 in mast cells. Potential role in survival promotion. J Biol Chem 1996; 271: 27500-27508.

12. Pearce FL, Thompson HL. Some characteristics of histamine secretion from rat peritoneal mast cells stimulated with nerve growth factor. J Physiol 1986; 372: 379-393.

13. Murakami M, Tada K, Nakajima K, Kudo I. Cyclooxygenase-2-dependent prostaglandin $\mathrm{D}_{2}$ generation is initiated by nerve growth factor in rat peritoneal mast cells: its augmentation by extracellular type II secretory phospholipase A $_{2}$. J Immunol 1997; 159: 439-446.

14. Tal M, Liberman R. Local injection of nerve growth factor (NGF) triggers degranulation of mast cells in rat paw. Neurosci Lett 1997; 22: 129-132.

15. Braun A, Appel E, Baruch R, et al. Role of nerve growth factor in a mouse model of allergic inflammation and asthma. Eur J Immunol 1998; 28: 3240-3251.

16. Hoyle GW, Graham RM, Finkelstein JB, Nguyen K-PT, Gozal D, Friedman M. Hyperinnervation of the airways in transgenic mice overexpressing nerve growth factor. Am J Respir Cell Mol Biol 1998; 18: 149-157.

17. de Vries A, Dessing MC, Engels F, Henricks PAJ, Nijkamp FP. Nerve growth factor induces a neurokinin-1 receptor-mediated airway hyperresponsiveness in guinea pigs. Am J Respir Crit Care Med 1999; 159: 1541-1544.

18. Frossard N, Olgart C, Naline E, et al. Increased production of NGF by IL-1 and bronchial hyperresponsiveness (abstract). Fundam Clin Pharmacol 2001; 15: 60 .

19. Fox AJ, Patel HJ, Barnes PJ, Belvisi MG. Release of nerve growth factor by human pulmonary epithelial cells: role in airway inflammatory diseases. Eur J Pharmacol 2001; 424: 159-162.

20. Pons F, Freund V, Kuissu H, Mathieu E, Olgart C, Frossard N. Nerve growth factor secretion by human lung epithelial A549 cells in pro- and antiinflammatory conditions. Eur J Pharmacol 2001; 428: 365-369.

21. Olgart C, Frossard N. Human lung fibroblasts secrete nerve growth factor: effect of inflammatory cytokines and glucocorticoids. Eur Respir J 2001; 18: 115-121.

22. Ueyama T, Hamada M, Hano T, Nishio I, Masuyama Y, Furukawa S. Production of nerve growth factor by cultured vascular smooth muscle cells from spontaneously hypertensive and Wistar-Kyoto rats. J Hypertens 1993; 11: 1061-1065.

23. Creedon DJ, Tuttle JB. Synergistic increase in nerve growth factor secretion by cultured vascular smooth muscle cells treated with injury-related growth factors. J Neurosci Res 1997; 47: 277-286.

24. Chomczynski P, Sacchi N. Single step of RNA isolation by acid guanidinium thiocyanate-phenolchloroform extraction. Anal Biochem 1987; 162: 156159.

25. Kassel O, Schmidlin F, Duvernelle C, Gasser B, Massard G, Frossard N. Human bronchial smooth muscle cells in culture produce stem cell factor. Eur Respir J 1999; 13: 951-954.

26. Kassel O, Schmidlin F, Duvernelle C, de Blay F, Frossard N. Up-and down-regulation by glucocorticoids of the constitutive expression of the mast cell growth factor SCF by human lung fibroblasts in culture. Molec Pharmacol 1998; 54: 1073-1079.

27. Leon A, Buriani A, Dal Toso R, et al. Mast cells synthesize, store, and release nerve growth factor. Proc Natl Acad Sci USA 1994; 91: 3739-3743.

28. Lambiase A, Bracci-Laudiero L, Bonini S, et al. Human CD4+ T cell clones produce and release nerve growth factor and express high-affinity nerve growth factor receptors. J Allergy Clin Immunol 1997; 100: 408-414.

29. Torcia M, Bracci-Laudiero L, Lucibello $\mathbf{M}$, et al. Nerve growth factor is an autocrine survival factor for memory B lymphocytes. Cell 1996; 85: 345-356.

30. Mallat M, Houlgatte R, Brachet P, Prochiantz A. Lipopolysaccharide-stimulated rat brain macrophages release NGF in vitro. Dev Biol 1989; 133: 309-311.

31. Olgart-Höglund C, de Blay F, Oster JP, et al. Nerve growth factor levels and localisation in human asthmatic bronchi. Eur Respir J 2002 (in press).

32. Kassel O, de Blay F, Duvernelle C, et al. Local increase in the number of mast cells and expression of nerve growth factor in the bronchus of asthmatic patients after repeated inhalation of allergen at low dose. Clin Exp Allergy 2001; 31: 1432-1440.

33. Barnes PJ, Chung KF, Page CP. Inflammatory mediators in asthma: an update. Pharmacol Rev 1998; 50: 515-596.

34. Tillie-Leblond I, Pugin J, Marquete $\mathrm{CH}$, et al. Balance between proinflammatory cytokines and their inhibitors in bronchial lavage from patients with status asthmaticus. Am J Respir Crit Care Med 1999; 159: 487-494.

35. Emmett C, McNeeley PA, Johnson RM. Evaluation of human astrocytoma and glioblastoma cell lines for nerve growth factor release. Neurochem Int 1997; 30 : 465-474.

36. Barnes PJ. Pharmacology of airway smooth muscle. Am J Respir Crit Care Med 1998; 158: 123-132.

37. Chung KF. Airway smooth muscle cells: contributing to and regulating airway mucosal inflammation? Eur Respir J 2000; 15: 961-968.

38. Chung KF, Patel H, Faldon EJ, et al. Induction of eotaxin expression and release from human airway smooth muscle cells by IL-1 $\beta$ and TNF $\alpha$ : effects of IL-10 and corticosteroids. Br J Pharmacol 1999; 127: $1145-1150$.

39. Saunders MA, Mitchell JA, Seldon PM, et al. Release of granulocyte-macrophage colony stimulating factor by human cultured airway smooth muscle cells: suppression by dexamethasone. $\mathrm{Br} J$ Pharmacol 1997; 120: 545-546.

40. Lee W, Mitchell P, Tijan R. Purified transcription factor AP-1 interacts with TPA-inducible enhancer element. Cell 1987; 49: 741-745. 
41. Cartwright M, Martin S, D'Mello S, Heinrich G. The human nerve growth factor gene: structure of the promoter region and expression in L929 fibroblasts. Mol Brain Res 1992; 15: 67-75.

42. Ammitt AJ, Bekir SS, Johnson P, Hughes M, Armour C, Black J. Mast cell numbers are increased in the smooth muscle of human sensitized isolated bronchi. Am J Respir Crit Care Med 1997; 155: 1123 1129.

43. Brodie DH, Lötz M, Cuomo AJ, Coburn DA, Federman EC, Wasserman SI. Cytokines in symptomatic asthmatic airways. J Allergy Clin Immunol 1992; 89: 958-967.

44. Bonini S, Lambiase A, Bonini S, et al. Circulating nerve growth factor levels are increased in humans with allergic diseases and asthma. Proc Natl Acad Sci USA 1996; 93: 10955-10960.

45. Undem BJ, Hunter DD, Liu M, Haak-Fredscho M, Oakragly A, Fischer A. Allergen-induced sensory neuroplasticity in airways. Int Arch Allergy Immunol 1999; 118: 150-153.

46. Sanico AM, Koliatsos VE, Stanisz AM, Bienenstock J, Togias A. Neural hyperresponsiveness and nerve growth factor in allergic rhinitis. Int Arch Allergy Immunol 1999; 118: 154-158.

47. Virchow JC, Julius P, Lommatzsch M, Luttmann W, Renz H, Braun A. Neurotrophins are increased in bronchoalveolar lavage fluid after segmental allergen provocation. Am J Respir Crit Care Med 1998; 158: 2002-2005. 